\title{
A parametric study on cyclic strength of coastal sand of Digha in West Bengal, India
}

\author{
Pinak Ray ${ }^{*}$ and Ramendu Bikas Sahu
}

*Correspondence: pinak.ray@gmail.com Department of Civil Engineering, Jadavpur University, Kolkata, West Bengal 700032, India

\begin{abstract}
Stress controlled cyclic triaxial tests have been carried out on coastal sand of Digha, West Bengal, India at different frequencies, confining pressures, relative densities and number of loading cycles for determination of influence of these parameters on cyclic strength (expressed in terms of cyclic stress ratio) and initial liquefaction of Digha sand. The test results provide evidence that increasing density of sand increases liquefaction potential, though it has been found that increase in effective confining pressure reduces cyclic strength of sand. Cyclic strength of sand decreases with increase of number of loading cycles at a specific density and a particular confining pressure. It has been observed that frequency of loading cycles does have any significant influence on the number of cycles for initial liquefaction of Digha sand. An empirical correlation has been developed on cyclic strength of sand based on these parameters and it has been found that this correlation fits quite well with the observed experimental results.
\end{abstract}

Keywords: Cyclic strength, Density of sand, Effective confining pressure, Initial liquefaction, Cyclic triaxial test

\section{Introduction}

The high incidence of liquefaction during earthquakes and its damage potential has made analysis of cyclic strength of sand a prime subject of concern in the field of geotechnical earthquake engineering. Significant research on liquefaction of soils has been carried out earlier by several researchers i.e. Seed and Lee [37], Lee and Seed [25], Peacock and Seed [30], Lee and Albaisa [23], Lee and Fitton [24], Saxena et al. [36], Seed and Peacock [39], Finn et al. [11], De Alba et al. [8], Hosri et al. [9] and Silver et al. [41]. What is soil liquefaction, how liquefaction of soil would be triggered, how to evaluate liquefaction potential of a soil and what are the factors affecting soil liquefaction potential have been understood from the research works of these researchers.

But in India the study of dynamic soil properties and liquefaction potential of soil has been started in a little later stage only after devastation and enormous damage have been occurred due to Bhuj earthquake in Gujarat in the year 2001. One type of study has been carried out on soil collecting from seismological active zones like Assam sand (Sitharam and Govindaraju 2007) and on soils from earthquake affected damaged areas like Ahmedabad sand (Sitharam and Govindaraju, 2007) and Bhuj sand [42]. Another type of study has been done on river sand like Kasai river sand [5], Solani river sand [27],

(c) The Author(s) 2021. This article is licensed under a Creative Commons Attribution 4.0 International License, which permits use, sharing, adaptation, distribution and reproduction in any medium or format, as long as you give appropriate credit to the original author(s) and the source, provide a link to the Creative Commons licence, and indicate if changes were made. The images or other third party material in this article are included in the article's Creative Commons licence, unless indicated otherwise in a credit line to the material. If material is not included in the article's Creative Commons licence and your intended use is not permitted by statutory regulation or exceeds the permitted use, you will need to obtain permission directly from the copyright holder. To view a copy of this licence, visit http://creativeco mmons.org/licenses/by/4.0/. 
Brahmaputra river sand [21], Yamuna sand [33] in order to evaluate their behavior during earthquake. But very less importance has been given on determination of liquefaction potential and the factors affecting soil liquefaction on coastal soils in India by early researchers.

India is surrounded by sea in eastern region (Bay of Bengal), southern region (Indian Ocean) and western region (Arabian Sea) and is very often experience oceanic storms along with large impact of tidal waves at least once in every year mainly during monsoon. Recently on May, 2020 devastating cyclone Amphan has made severe damage in the coastal areas in West Bengal comprising East Midnapur and South 24 Parganas. In the year 2000, eastern and southern coast experienced the effect of tsunami which caused a devastating damage in the coastal area. Several research works on liquefaction of soils have been performed on coastal soil has been done in other countries like sand from the North Coast of Egypt [34], Calcareous coastal soil from Australia [40], sand from beach in Puerto Real, Cabo Rojo, south-western Puerto Rico [35] and coastal sand from Dogs Bay [12], but in India, especially in its eastern coast part, liquefaction analysis of coastal sand has not been performed by earlier researchers.

Based on this point of view, a detail study on coastal sand of Digha region (which is in eastern coast of India) [19] has been selected for this present study. Digha is situated between the coastal tract of adjacent Bay of Bengal and the boarder of two states: West Bengal and Orissa [19, 28, 31]. Moreover this area lies within the seismic zone III [7]. Digha is one of the most important and densely crowded tourist spots of West Bengal district and it consists of one of the biggest fishery industry in India [28]. So all types of important structures used by tourism and fishery industries along with residential and industrial buildings have been constructed on the soil of Digha, which is more or less uniform fine to medium sand $[3,6,18]$. In recent past several number of earthquake ground shakings have occurred in Digha region [13] due to Pingla Fault and Garhmayna Khandaghosh Fault [7]. So there exists a high chance of damage due to liquefaction if earthquake of high magnitude strikes in this region.

In this regard, a detail study to determine liquefaction potential, excess pore water pressure generation and identification of the effects of all the parameters on liquefaction potential of coastal sand of Digha has been found immense important. The study area, which was selected, has been shown in the map from Fig. 1a-c.

\section{Background}

Failure of soil during liquefaction can be defined as when maximum excess pore water pressure $\left(\mathrm{u}_{\max }\right)$ becomes equal to effective over burden pressure or effective consolidation stress $\left(\sigma_{\mathrm{o}}\right)$. So it can be stated that liquefaction of soil occurs for that particular number of cycle when pore water pressure ratio $\left(r_{u}\right)$ equals to 1 (i.e. $\left.r_{u}=u_{\max } / \sigma_{o}=1\right)$ and that particular number of cycle can be designated as number of cycles required for initial liquefaction $\left(\mathrm{N}_{\mathrm{L}}\right)$. Various methods have been proposed by several researchers to evaluate liquefaction potential of soil by performing laboratory tests (i.e. cyclic triaxial tests, cyclic simple shear tests, cyclic torsional shear tests, resonant column tests etc.), model tests (i.e. shake table tests) and field tests (i.e. standard penetration resistance tests, field blast studies etc.). Out of these techniques the most simplified and widely used laboratory test is cyclic triaxial 


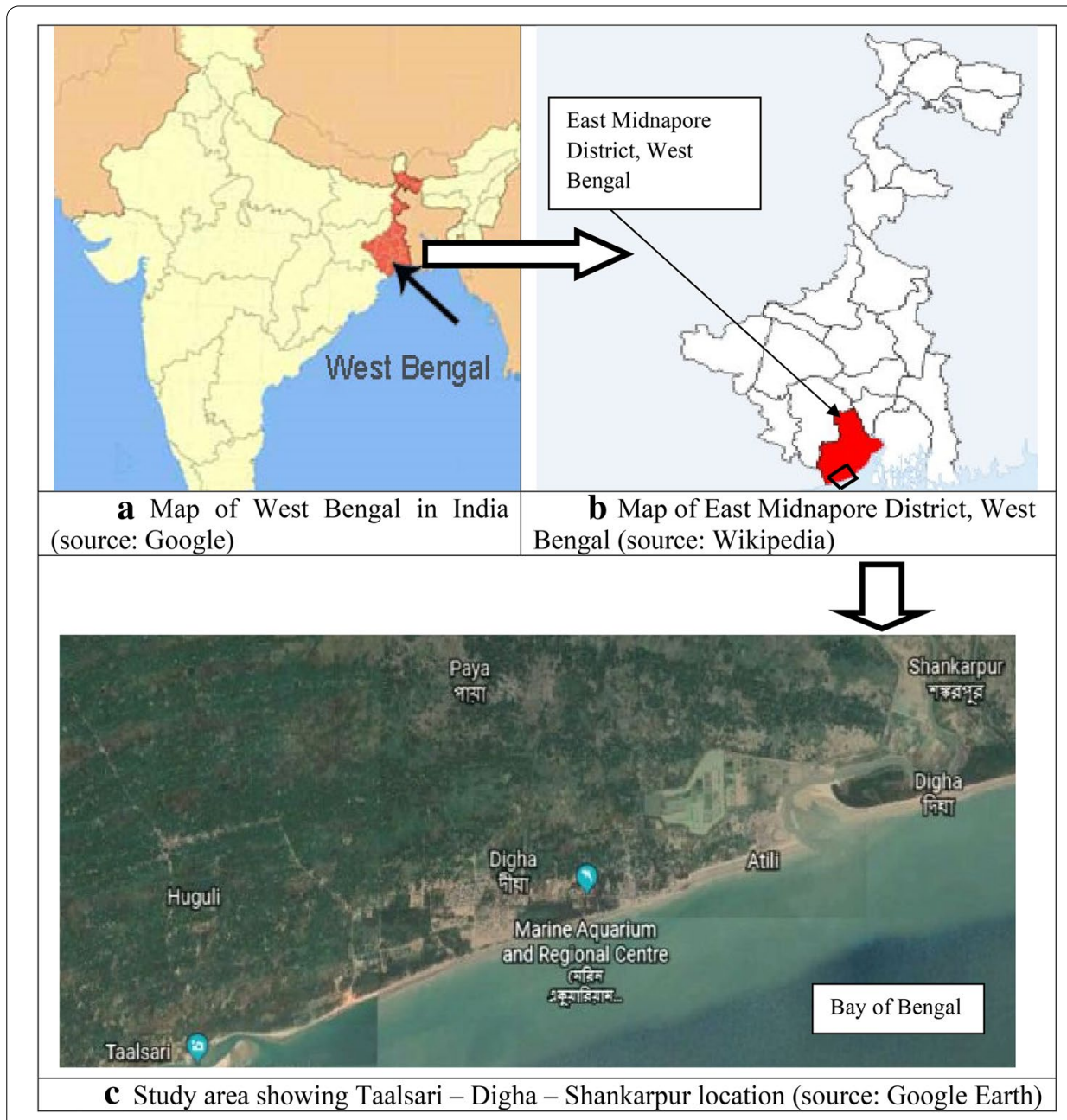

Fig. 1 a Map of West Bengal in India (source: Google). b Map of East Midnapore District, West Bengal (source: Wikipedia). c Study area showing Taalsari-Digha-Shankarpur location (source: Google Earth)

test. Both stress controlled cyclic triaxial tests $[5,29]$ and strain controlled cyclic triaxial tests [21] can be performed to evaluate liquefaction potential of soil and both these types have certain advantages and disadvantages [48].

In case of stress controlled cyclic triaxial test, the most suitable method is determination of number of cycles required for initial liquefaction for a given Cyclic Stress Ratio (CSR), where the term cyclic stress ratio can be defined as the ratio of cyclic shear stress, $\tau_{\text {cyc }}$ to the effective over burden pressure, $\sigma_{o}$ (i.e. CSR $=\tau_{\text {cyc }} / \sigma_{o}$ ). But this failure criteria $\left(\mathrm{N}_{\mathrm{L}}\right)$ is determined by for that cycle when $r_{u}$ reaches 1 or axial strain of the sample reaches $5 \%$ (double amplitude strain, $\varepsilon_{\mathrm{d}}=5 \%$ ), whichever is earlier. Several attempts have been made by researchers to find the effects of parameters which affect the cyclic strength of soil. Out of these most important parameters are: relative density (soil characteristic), effective confining pressure (geological criteria), and number of cycles of loading during earthquake and frequency of loading during earthquake (seismic criteria).

The effect of number of cycles required for liquefaction (seismic criteria) on CSR has been investigated by earlier researchers $[10,26,34,37,38,41,46]$. The effect of 
frequency on cyclic strength of soil (seismic criteria) has been investigated by Rao and Ramana [33], Townsend [47]. How the relative density (soil characteristic) affect the liquefaction potential has been shown by the research works of Seed and Lee [37], Lin et al. [26], Finn et al. [11], Hyodo et al. [12], Sandoval and Pando [35], Salem et al. [34], Krim et al. [20] and Rao and Ramana [33]. The effect of effective confining pressure (geological criteria) on soil liquefaction has been studied and analyzed by Castro and Poulos [4], Yunoki et al. [50], Salem et al. [34], Finn et al. [11], Peacock and Seed [30], Seed and Lee [37], Hyodo et al. [12] and Rao and Ramana [33].

The results of these effects of parameters on soil liquefaction by the researchers have been found somehow contradicting to each other. Though it has been shown that frequency of loading cycle does not affect the soil liquefaction by Rao and Ramana [33], the contradicting finding has been found by Townsend [47]. Moreover, there exists a very confusing outcome on the effect of effective confining pressure on soil liquefaction. Salem et al. [34], Finn et al. [11], Castro and Poulos [4], Sandoval and Pando [35] have shown cyclic strength of soil reduces with the increase of effective confining pressure on soil, whereas contradicting nature has been observed by Seed and Lee [37], Peacock and Seed [30], Rao and Ramana [33], where it has been observed that the number of cycles to liquefy increases with the increase of effective confining pressure. In an addition to this contradicting result, Yunoki et al. [50] and Ishihara et al. [17] have indicated that there was no effect of effective confining pressure on the behaviour of silica sands for relative densities ranging from 50 to $70 \%$. The effect of the effective confining pressure on number of cycles to failure in case of calcareous sands has been found unclear as per Hyodo et al. [12].

In this regard, determination of the effect of all the parameters on liquefaction potential of siliceous coastal sand of Digha (situated in eastern coast of India) has been found very much essential. An attempt has been made to develop a unique numerical model to establish the correlationship between cyclic strength of Digha sand with all the parameters affecting liquefaction potential. Correlation between cyclic strength of sand (CSR) with number of cycles required to reach initial liquefaction $\left(\mathrm{N}_{\mathrm{L}}\right)$ has been proposed earlier [5, 32].

$$
C S R=a N_{L}^{-b}
$$

In Eq. (1), the coefficients ' $a$ ' and ' $b$ ' depend on the density of sand. The values of ' $a$ ' and ' $b$ ' obtained from the experimental results, have been reported by Rad and Clough [32]; Chattaraj and Sengupta [5] and it was observed that the values of coefficients 'a' and ' $b$ ' have been increased along with density of sand. The major drawback of this equation was the coefficients ' $a$ ' and ' $b$ ' depend on only relative density of sand taking effective confining pressure constant $(100 \mathrm{kPa})$ though CSR is highly dependent on effective confining pressure, found by other researchers [4, 30, 33, 34, 37].

In this regard, a series of stress controlled cyclic triaxial tests have been carried on coastal Digha sand to determine its cyclic strength (CSR) by considering the parameters of frequency of loading, density of sand, effective confining pressure and number of cycles of loading which causes liquefaction and an attempt has been made to establish a new unique correlation of cyclic strength of coastal Digha sand with these parameters. 
Table 1 Physical properties of Digha sand

\begin{tabular}{lll}
\hline Property & Notations & Value \\
\hline Specific gravity & $\mathrm{G}_{\mathrm{s}}$ & 2.72 \\
Grain size $(\mathrm{mm})$ & $\mathrm{D}_{60}$ & 0.3 \\
& $\mathrm{D}_{50}$ & 0.26 \\
& $\mathrm{D}_{30}$ & 0.19 \\
Uniformity coefficient & $\mathrm{D}_{10}$ & 0.123 \\
Coefficient of curvature & $\mathrm{C}_{\mathrm{u}}$ & 2.44 \\
Maximum dry density $(\mathrm{gm} / \mathrm{cc})$ & $\mathrm{C}_{\mathrm{c}}$ & 0.978 \\
Minimum dry density $(\mathrm{gm} / \mathrm{cc})$ & $\mathrm{V}_{\mathrm{dmax}}$ & 1.61 \\
Maximum void ratio & $\mathrm{V}_{\mathrm{dmin}}$ & 1.37 \\
Minimum void ratio & $\mathrm{e}_{\max }$ & 0.978 \\
Soil type & $\mathrm{e}_{\min }$ & 0.692 \\
& $\mathrm{SP}$ & Poorly \\
& & graded \\
& & sand \\
\hline
\end{tabular}

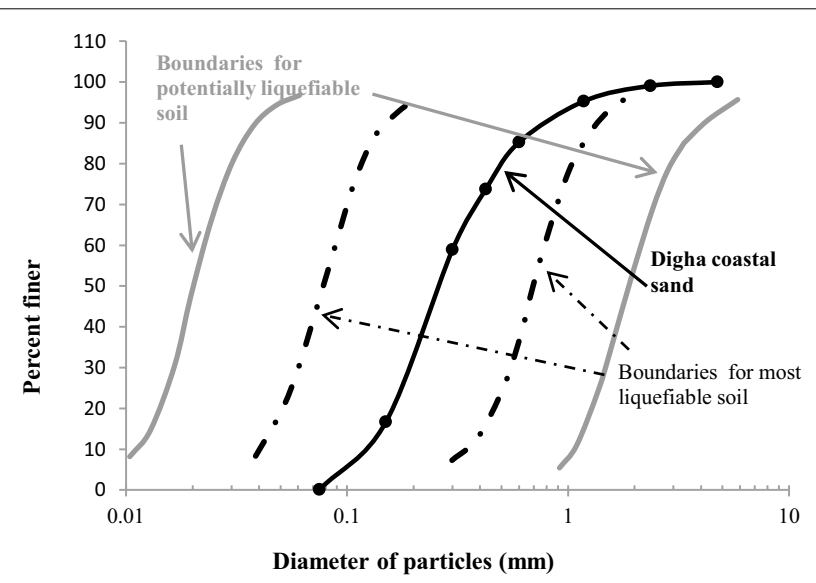

Fig. 2 Grain size distribution curve of Digha sand with liquefiable boundaries

\section{Material characteristics}

The coastal Digha sand in this present study has been collected from Taalsari (DighaShankarpur region) shown in Fig. 1c having coordinates $21^{\circ} 37^{\prime} 59.196^{\prime \prime}$ Northern Latitude and $87^{\circ} 32^{\prime} 37.2732^{\prime \prime}$ Eastern Longitude. The index properties of Digha sand has been determined as per IS: 1498 [14], IS: 2720 (Part-3) [15], and IS: 2720 (Part14) [16] and shown in Table 1 and the grain size distribution curve is shown in Fig. 2. The sand specimen, used in this study, has been collected from Digha region and it has been found yellowish colour sand (shown in Fig. 3). The soil has been classified as poorly graded sand (SP) as per ASTM D 2487 [1]. It has been seen in Fig. 2 that the grain size distribution curve lies between liquefiable boundaries proposed by [45] and reproduced by [49]. So it may be concluded from Fig. 2 that the sand sample which has been selected has high liquefaction susceptibility. 


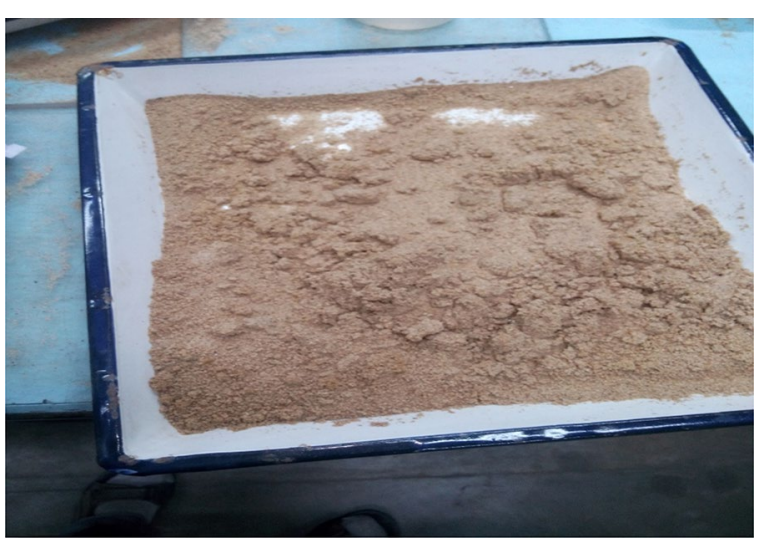

Fig. 3 Sand sample collected from coastal Digha region

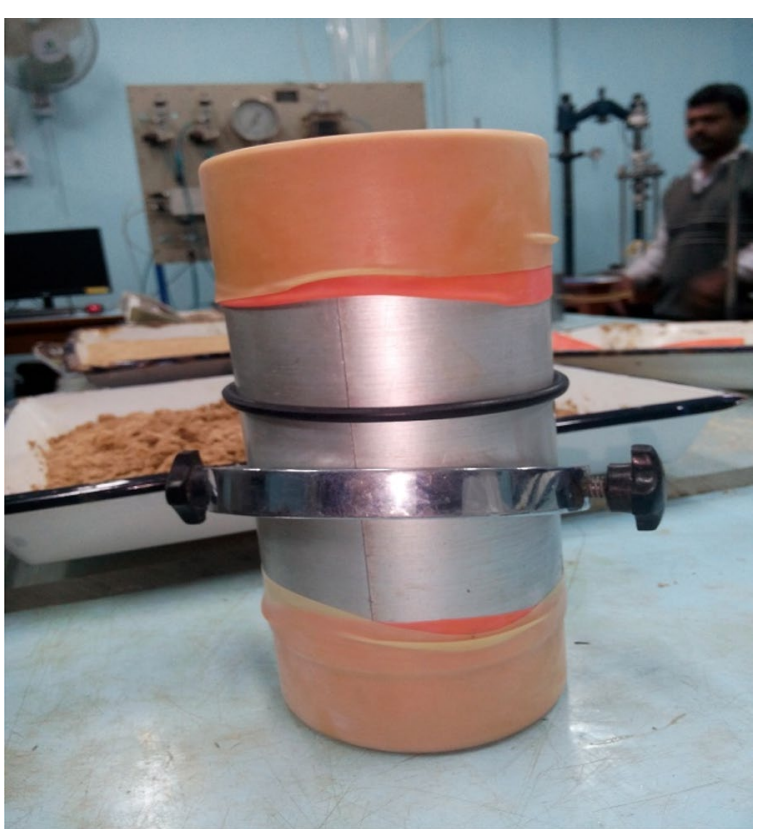

Fig. 4 Soil sample in split mould

\section{Sample preparation}

For cyclic triaxial test all the soil samples have been prepared by a cylindrical split mould of size $50 \mathrm{~mm}$ diameter and $100 \mathrm{~mm}$ height (shown in Fig. 4). As per ASTM 5311-11 [2] the oven dried sand samples have been prepared by tamping method in 5 layers. If the target relative density is $R_{d} \%$, then relative densities have been targeted from the bottom most to the top most layers are $R_{d}-2, R_{d}-1, R_{d}, R_{d}+1, R_{d}+2 \%$ respectively. By selecting the target relative density for each layer the weight of sand along with height of each layer to be maintained has been calculated [22]. A cone shaped funnel with a long tube has been used to pour the specimen into the split mould for each layer by maintaining zero dropping height. After filling each layer into 
the mould, tamping is applied till it occupies the particular height for each layer. Suction pressure of 10-12 kPa was applied to the sample at the bottom to make the sample tight, vertical and to reduce disturbance before removing the mould. So, after the split mould is removed the dry sand sample (after reaching the particular target relative density) stands on its own weight inside the rubber membrane and takes uniform cylindrical shape having diameter $=50 \mathrm{~mm}$ and height $=100 \mathrm{~mm}$ (shown in Fig. 5).

Four target relative densities of $25 \%, 45 \%, 65 \%$ and $85 \%$ have been selected in this present study along with four different effective confining pressures of $50 \mathrm{kPa}$, $100 \mathrm{kPa}, 200 \mathrm{kPa}$ and $400 \mathrm{kPa}$. Saturation has been done with de aired distilled water by applying back pressure and it has been increased gradually by maintaining the effective confining pressure (difference between cell pressure and back pressure) $10 \mathrm{kPa}$ until Skempton's pore pressure coefficient value [43], $\mathrm{B}=\Delta \mathrm{u} / \Delta \sigma_{\mathrm{c}}$, (where $\Delta \mathrm{u}$ is change in pore water pressure and $\Delta \sigma_{\mathrm{c}}$ is change in cell pressure) exceeded 0.95. During saturation back pressure (B.P.) has been raised to $500 \mathrm{kPa}$ and cell pressure (C.P.) has been raised to $510 \mathrm{kPa}$. Then the sand sample has been consolidated isotropically by maintaining the effective confining pressure $\left(\sigma_{\mathrm{o}}\right)$ value of that amount in which the test program has been decided to conduct i.e. $\sigma_{\mathrm{o}}=50,100,200$ and $400 \mathrm{kPa}$. The test conditions of effective confining pressure (during consolidation and thereafter cyclic loading) have been obtained by keeping the difference between cell pressure and back pressure as follows:

The effective confining pressure $\left(\sigma_{0}\right)$ values have been obtained by keeping C.P. $=550 \mathrm{kPa}$ and B.P. $=500 \mathrm{kPa}\left(\right.$ for $\left.\sigma_{\mathrm{o}}=50 \mathrm{kPa}\right) ;$ C.P. $=600 \mathrm{kPa}$ and B.P. $=500 \mathrm{kPa}$ (for $\sigma_{\mathrm{o}}=100 \mathrm{kPa}$ ); C.P. $=700 \mathrm{kPa}$ and B.P. $=500 \mathrm{kPa}\left(\right.$ for $\left.\sigma_{\mathrm{o}}=200 \mathrm{kPa}\right)$; C.P. $=900 \mathrm{kPa}$ and B.P. $=500 \mathrm{kPa}\left(\right.$ for $\left.\sigma_{\mathrm{o}}=400 \mathrm{kPa}\right)$.

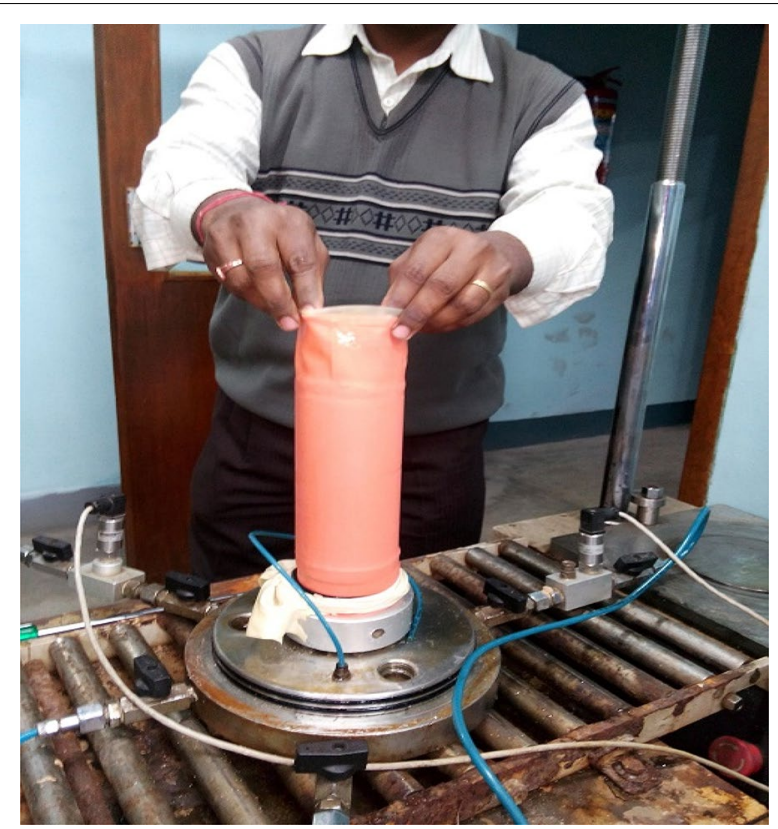

Fig. 5 Soil sample placed on base pedestal after removing split mould 


\section{Testing programme}

\section{Cyclic triaxial test}

The cyclic triaxial test has been conducted as per ASTM: 5311-11 [2] after completion of the consolidation process to determine cyclic strength (liquefaction potential) of soil by stress controlled technique. The saturated and consolidated sand specimen has been subjected to cyclic load by a loading rod which is connected to the top platen of the specimen under undrained condition by closing the back pressure valve in the loading frame (shown in Fig. 6). During application of cyclic load, the pore water pressure in the specimen increases. As a result, the effective stress in the specimen decreases and axial deformation of the specimen increases. The failure has been determined as that number of load cycles when excess pore water pressure ratio $\left(r_{u}\right)$ becomes equal to 1 , which is called initial liquefaction and that number of cycle to cause initial liquefaction is denoted as, $\mathrm{N}_{\mathrm{L}}$. These pore water pressure generations, cyclic loading on the soil specimen as well as axial deformation of the specimens have been displayed as well as recorded by the software provided by M/s HEICO named as Cyclic System Console V1.0.0 in a computer (shown in Fig. 7). The hydraulic actuator connected to a load cell (capacity $10 \mathrm{kN}$ ) which has been used in this test program can perform sinusoidal loading which can operate at a frequency of 0.01 to $10 \mathrm{~Hz}$ (shown in Fig. 8). The specimen can be tested at a confining pressure up to $1000 \mathrm{kPa}$ and the cell pressure and back pressure both can be applied by digitally controlled pressure system along with a control panel which has a combination of electro pneumatic regulators (shown in Fig. 9).

The test conditions for cyclic loadings by performing stress controlled tests have been achieved as follows

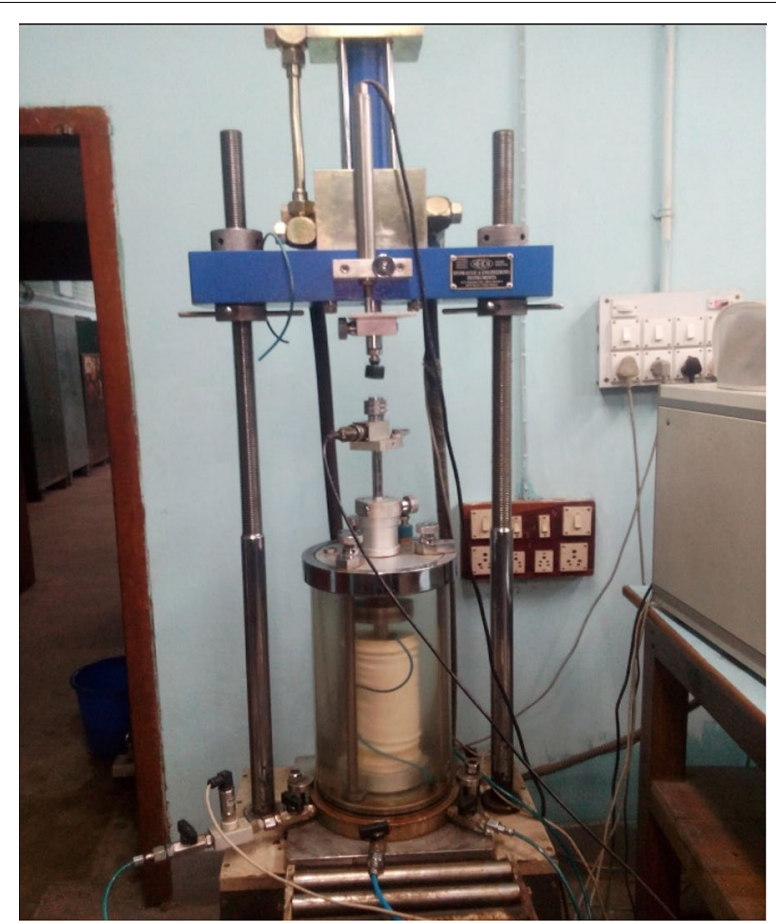

Fig. 6 Triaxial cell on the HEICO loading platformMap of West Bengal in India (source: Google) 


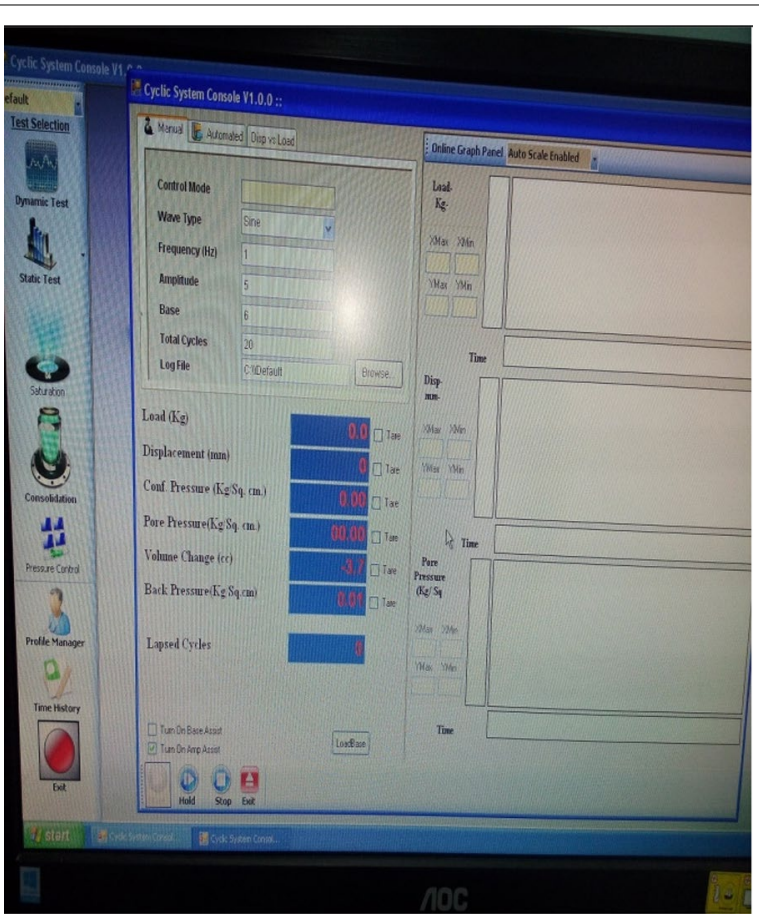

Fig. 7 Data acquisition system named Cyclic System Console V1.0.0

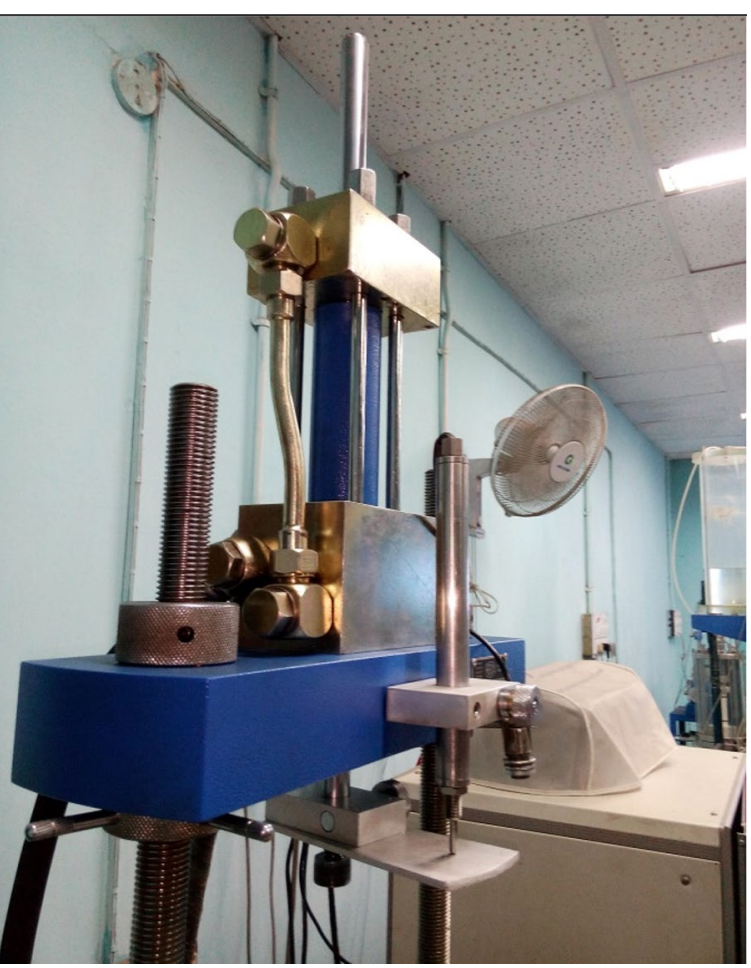

Fig. 8 Hydraulic actuator 


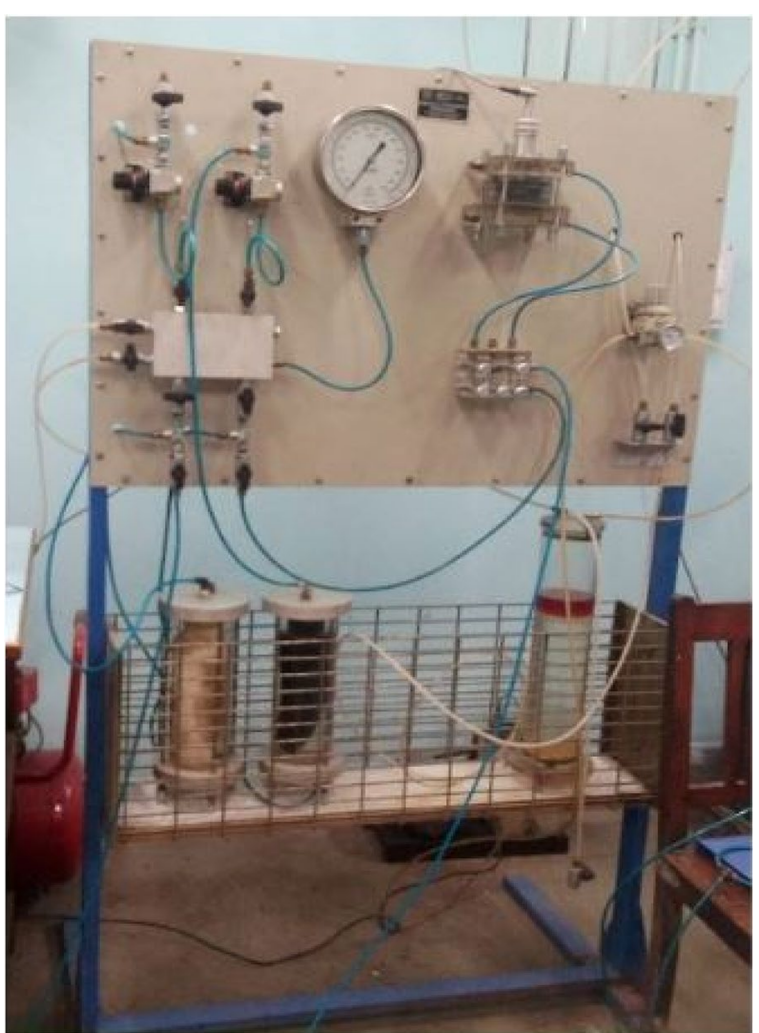

Fig. 9 Digitally controlled pressure system

The cyclic stress ratio value of $0.15,0.20 .25$ and 0.3 has been selected for soil sample having relative density of $25 \%$ and $45 \%$. For relative density $65 \%$ and $85 \%$ the CSR value has been chosen as $0.2,0.25,0.3$ and 0.35 . For each cyclic triaxial test the effective confining pressure has been varied as 50,100, 200 and $400 \mathrm{kPa}$. So total 64 stress controlled cyclic triaxial test has been done in this study at sinusoidal harmonic loading having an applied constant frequency of $1 \mathrm{~Hz}$. To study effect of frequency on liquefaction potential four sets of cyclic triaxial tests have been performed, where during the each set of test at a particular relative density and a particular effective confining pressure, the frequency range has been varied as $0.5,1$ and $2 \mathrm{~Hz}$.

\section{Results and discussion}

\section{Cyclic triaxial test results}

Typical test results of stress controlled cyclic triaxial test for coastal Digha sand has been shown in Fig. 10a-c. All the cyclic triaxial tests have been performed as two way cyclic loading which means reversal of cyclic shear stresses (compression and extension at a single cycle of loading). For the stress-controlled cyclic triaxial test, the magnitude of applied deviator stress, $\sigma_{\mathrm{d}}(\mathrm{kPa})$ has been estimated from the cyclic stress ratio (CSR) value and the particular effective confining pressure during the cyclic test by using Eq. (2).

$$
\sigma_{d}=2 \times \sigma_{o} \times C S R
$$




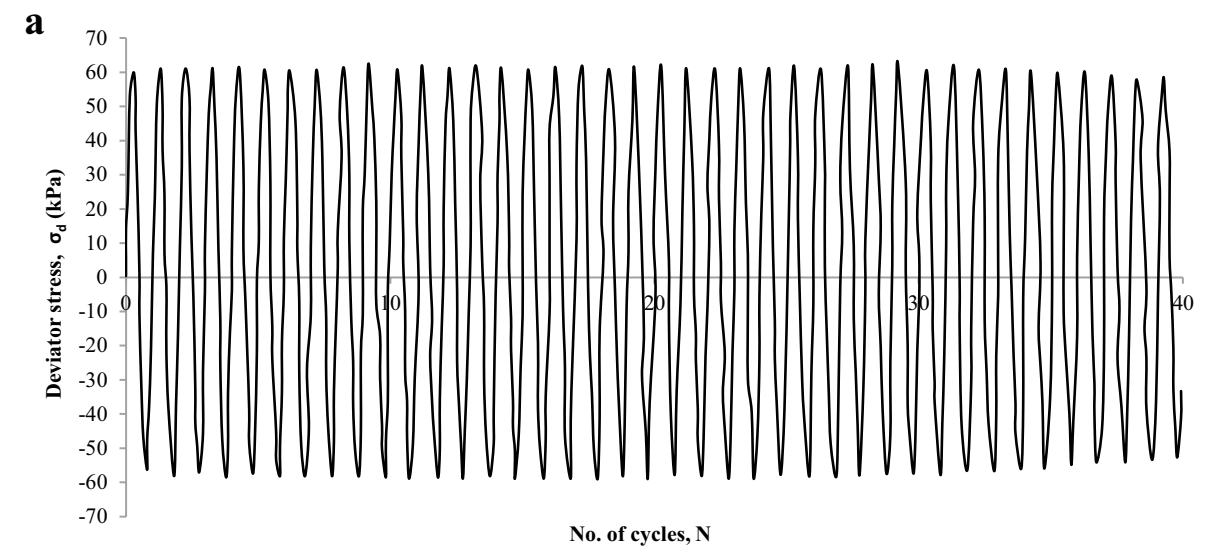

b
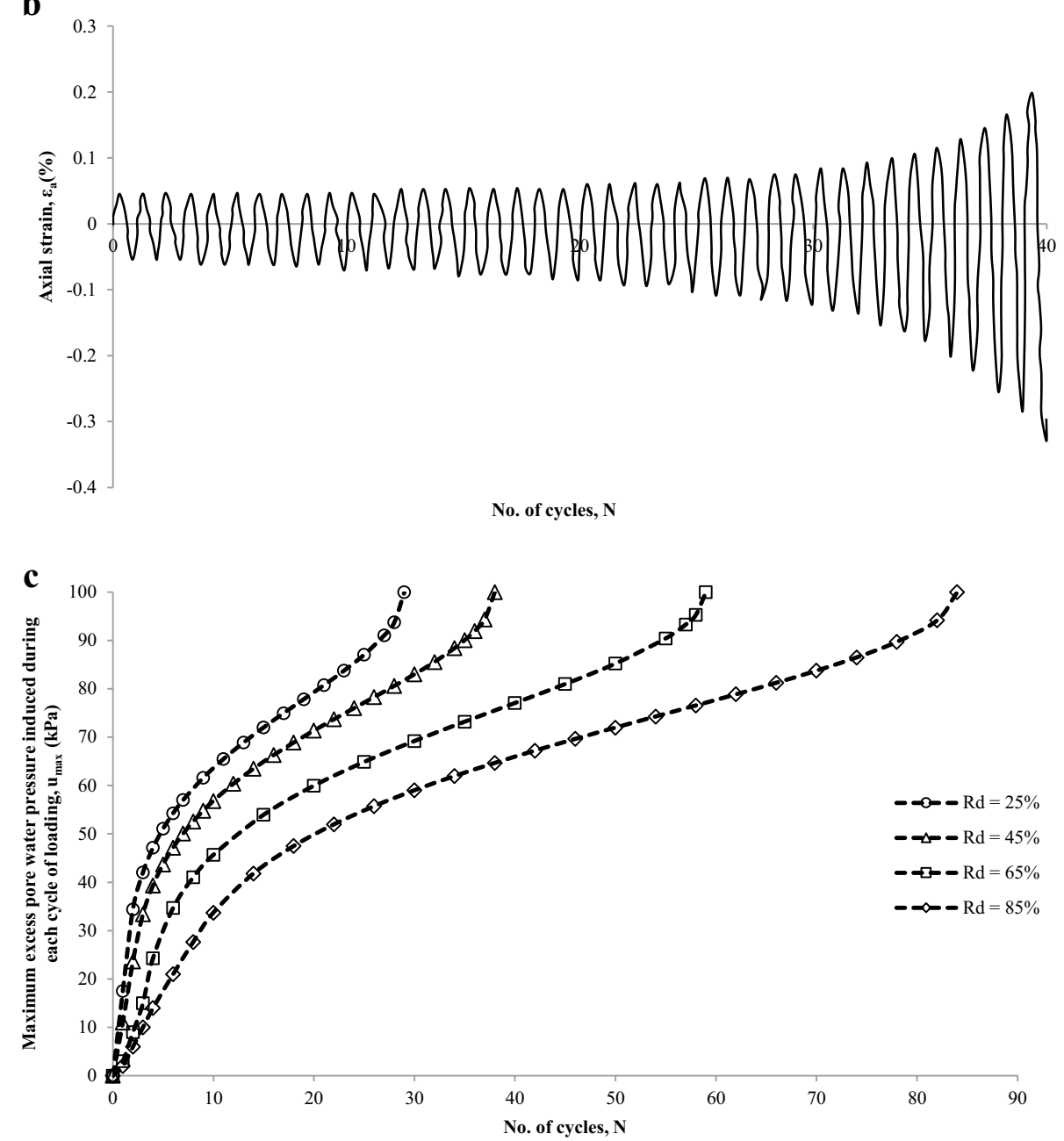

Fig. 10 a Typical test result of applied deviator stress vs. number of cycles during cyclic loading for Digha sand at $R_{d}=45 \%, \sigma_{o}=100 \mathrm{kPa}$, applied $C S R=0.3, f=1 \mathrm{~Hz}$. $\mathbf{b}$ Typical test result of response of axial strain vs. number of cycles during cyclic loading for Digha sand at $R_{d}=45 \%, \sigma_{0}=100 \mathrm{kPa}$, applied $\operatorname{CSR}=0.3, f=1 \mathrm{~Hz}$. c Typical test result of generation maximum excess pore water pressure induced during each cycle of loading vs. number of loading cycles during cyclic triaxial test for Digha sand at constant $\sigma_{0}=100 \mathrm{kPa}$, constant $\mathrm{CSR}=0.3$, with variation of all relative densities i.e. 25 to $85 \%$ 
Figure 10a shows the applied deviator stress vs. number of cycles during cyclic loading for coastal Digha sand while conducting stress controlled cyclic triaxial test at relative density $\left(R_{d}\right)=45 \%$, effective confining pressure $\left(\sigma_{o}\right)=100 \mathrm{kPa}$ and at applied cyclic stress ratio $(\mathrm{CSR})=0.3$.

So by using Eq. (2) it can be calculated the applied deviator stress is $60 \mathrm{kPa}$. As all the tests are stress controlled test so the applied deviator stress is constant throughout each entire test program. The response of soil sample during liquefaction has been found out in Fig. 10b from the graph of axial strain, $\varepsilon_{\mathrm{a}}$ (\%) vs. no. of loading cycles. It has been observed when the sample has started losing its strength (after 20th number of cycles the deformation of the sample starts increasing. When the sample fails due to rise of excess pore water pressure equal to effective confining pressure (at 38th number of cycles) the deformation of the sample becomes very large. The reason behind this phenomenon is that during liquefaction the sample loses its strength completely, so during application of cyclic loading by the actuator, the sample (which has lost its strength completely) deforms very high for applying the same amount of deviator stress (i.e. $60 \mathrm{kPa}$ ) with respect to non liquefied soil sample. The excess pore water pressure generation during cyclic loading has been illustrated in Fig. 10c for applied CSR $=0.3$ and effective confining pressure $=100 \mathrm{kPa}$ at four relative densities, i.e. $25 \%, 45 \%, 65 \%$ and $85 \%$. It has been observed that at lower value of relative density the soil loses its strength quickly rather than in dense state. So the generation of excess pore water pressure during cyclic loading is much faster for sand in loose state with respect to sand in dense state. Figure 10c depicts the generation of excess pore water pressure generation at a constant effective confining pressure of $100 \mathrm{kPa}$. So it has been found that when the maximum excess pore water pressure, $\mathrm{u}_{\max }$ has become equal to $100 \mathrm{kPa}$ (effective confining pressure), the liquefaction occurs in that soil sample. It has been clearly observed in Fig. 10c that for relative density $45 \%$ and applied CSR $=0.3$ the soil liquefies at $38^{\text {th }}$ number of loading cycles because at $38^{\text {th }}$ numbered cycle $u_{\max }$ has become equal to $100 \mathrm{kPa}$ (effective confining pressure). The four curves of excess pore water pressure generation have been shown to compare and understand the excess pore pressure generation with variation of relative density.

\section{Effect of frequency on cyclic strength of soil}

To investigate the effect of frequency on cyclic strength of soil cyclic triaxial tests have been done on coastal Digha sand at 3 frequencies i.e. 0.5, 1 and $2 \mathrm{~Hz}$. Soil sample has been prepared at $R_{d}=25 \%$ at $\sigma_{o}=50 \mathrm{kPa}$ and at $R_{d}=85 \%$ at $\sigma_{o}=100 \mathrm{kPa}$ (shown in Fig. 11a) and at $R_{d}=45 \%$ at $\sigma_{o}=400 \mathrm{kPa}$ and at $R_{d}=65 \%$ at $\sigma_{o}=200 \mathrm{kPa}$ (shown in Fig. 11b). For each frequency CSR value has been varied from 0.15 to 0.3 (for $R_{d}=25 \%$ and $45 \%$ ) and 0.2 to 0.35 (for $R_{d}=65 \%$ and $85 \%$ ). Figure 11 illustrates the effect of frequency on cyclic strength of soil. It has been found that frequency of load application does not influence the liquefaction resistance. Similar finding has been found by [33]. In this regard, all other cyclic triaxial tests have been done at sinusoidal loading frequency of $1 \mathrm{~Hz}$. 

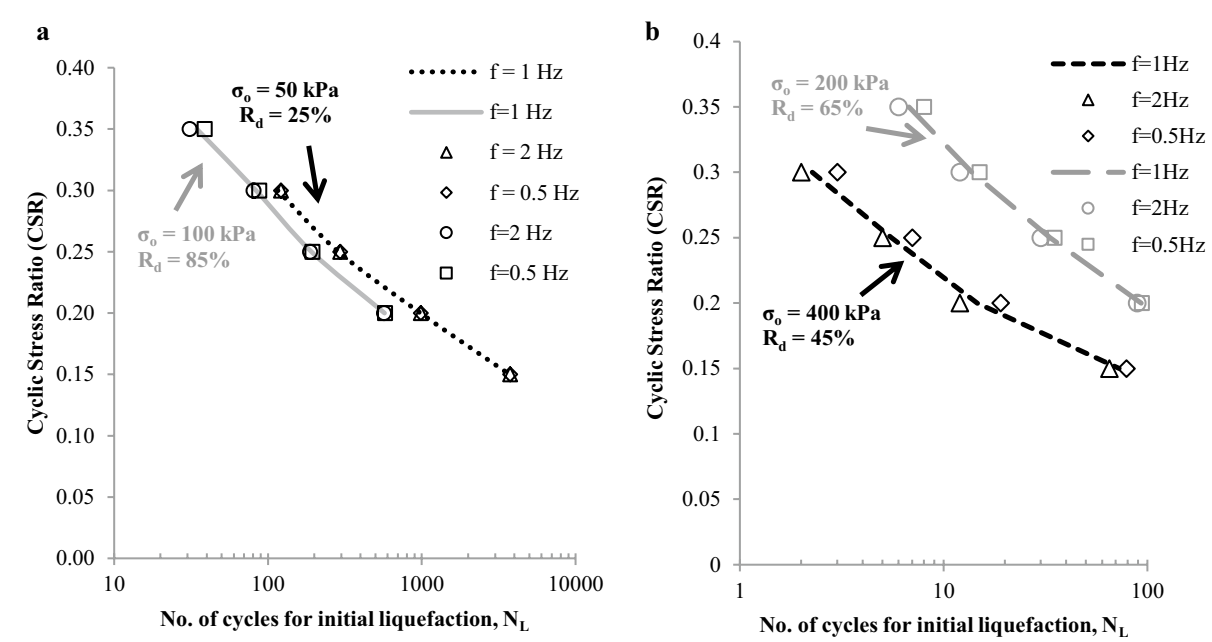

Fig. 11 Effect of frequency on CSR values of sand for $\mathbf{a} R_{d}=25 \%$ and $85 \%$ and $\mathbf{b} R_{d}=45 \%$ and $65 \%$

\section{Dependency of cyclic strength of soil on number of cycles}

Figure 12 illustrates the results of 64 numbers of cyclic triaxial tests. Soil sample has been prepared at relative density $25 \%, 45 \%, 65 \%$ and $85 \%$. For each density effective confining pressure of 50,100, 200 and $400 \mathrm{kPa}$ has been applied. CSR value of 0.15 to 0.3 has been taken for relative density $25 \%$ and $45 \%$ and CSR value of 0.2 to 0.35 has been taken for relative density $65 \%$ and $85 \%$. It has been found that CSR value of soil reduces non- linearly with increase of number of cycles to cause initial liquefaction, $\mathrm{N}_{\mathrm{L}}$. So it can be stated that increase in loading amplitude (CSR value) increase rapid acceleration of excess pore water pressure in soil, as a result lesser number of loading cycles are required to liquefy of sand. Similar trend has been found by previous researchers $[10,26$, $34,37,41,46]$.

\section{Effect of density and confining pressure on number of cycles to liquefy}

To analyze cyclic strength of sand on number of cycles to liquefy (shown in Fig. 12) and to determine the effects of parameter on liquefaction resistance of sand, a detail study has been done by concentrating only on the effect of density and confining pressure on number of cycles required for initial liquefaction $\left(\mathrm{N}_{\mathrm{L}}\right)$. Figure 13 shows the effect of effective confining pressure $\left(\sigma_{\mathrm{o}}\right)$ on number of cycles to liquefy for different cyclic stress ratios values i.e. 0.15 to 0.3 for $R_{d}=25 \%$ and for CSR values i.e. 0.2 to 0.35 for $R_{d}=85 \%$. It has been observed that number of cycles to liquefy for initial liquefaction decreases with increase in effective confining pressure (Fig. 13). Similar trend or similar nature has been observed by other researchers also [4, 34, 35, 44]. But this observation is contradicting in nature with observed result of other researchers [30,33,37] where number of cycles to liquefy increases with increase of effective confining pressure.

This observation can be explained like this as the sand has become saturated and consolidated before cyclic loading, so increase in effective confining pressure before application of shearing by cyclic loading squeezes the voids space between sand particles and increases the pore water pressure inside the sand for a certain amount. So when 


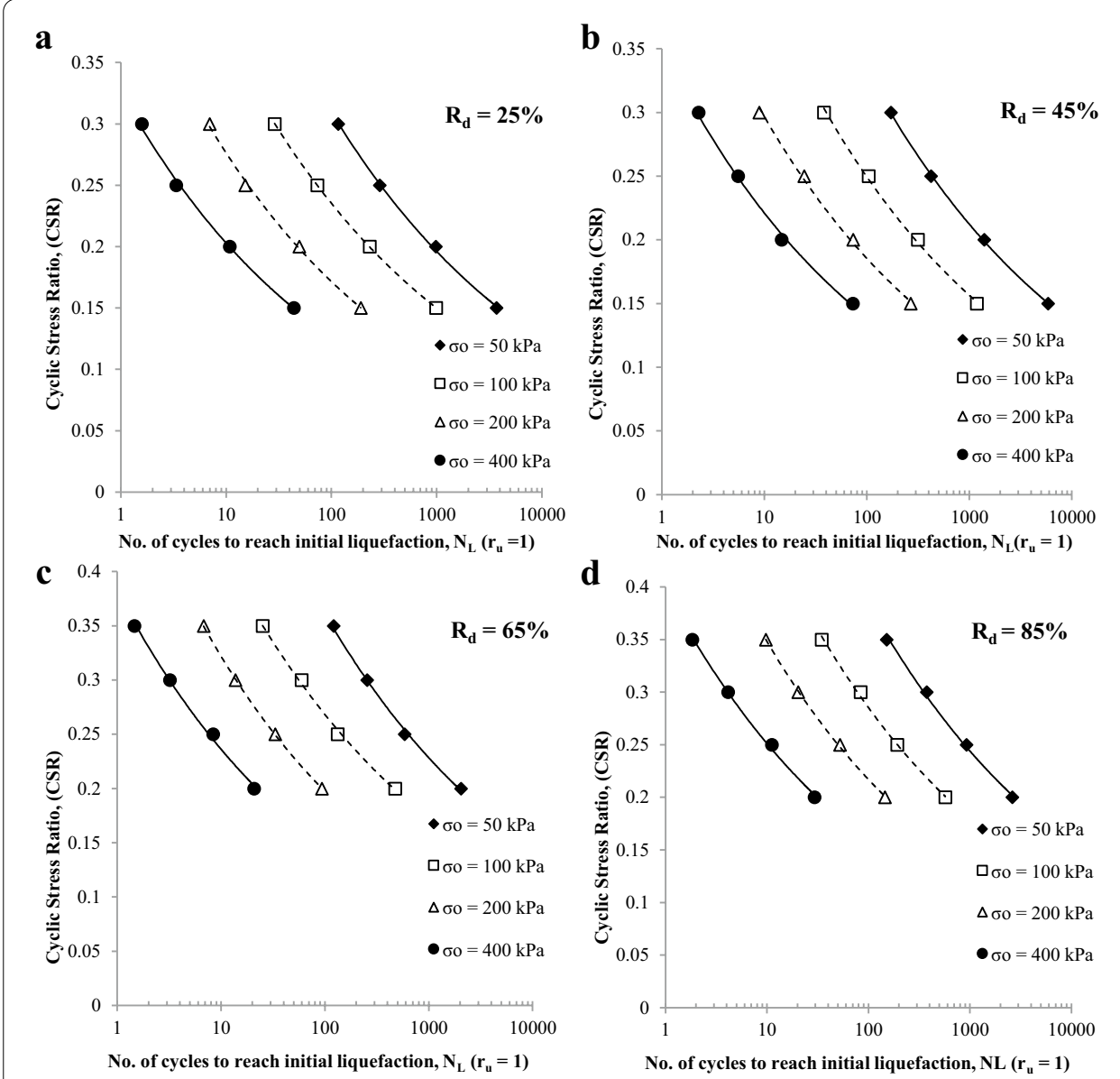

Fig. 12 Variation of cyclic stress ratio with number of cycles to reach initial liquefaction by varying confining pressures from $50 \mathrm{kPa}$ to $400 \mathrm{kPa}$ at $\mathbf{a} \mathrm{R}_{\mathrm{d}}=25 \% ; \mathbf{b} \mathrm{R}_{\mathrm{d}}=45 \% ; \mathbf{c} \mathrm{R}_{\mathrm{d}}=65 \%$; $\mathbf{d} \mathrm{R}_{\mathrm{d}}=85 \%$

cyclic loading has been applied to the sand sample lesser number of loading cycles are required to reach excess pore water pressure equal to effective confining pressure (initial liquefaction).

Figure 14 illustrates the effect of density on number of cycles required to liquefy. It has been observed that with increase in density, the strength of the soil sample increases. As a result more number of cycles required to liquefy dense sample rather lesser number of loading cycles are required to cause initial liquefaction of loose sample at a particular selected loading amplitude (CSR) for effective confining pressure $50 \mathrm{kPa}$ (Fig. 14a), $100 \mathrm{kPa}$ (Fig. 14b) and $200 \mathrm{kPa}$ (Fig. 14c), $400 \mathrm{kPa}$ (Fig. 14d). Similar findings have been found by other researchers also $[20,33,34]$.

\section{Representation of liquefaction potential in terms of CSR}

For better understanding the effects of effective confining pressure and density on liquefaction potential of Digha sand, a series of cyclic triaxial tests have been performed to determine cyclic stress ratio which causes initial liquefaction (development of excess pore water pressure ratio, $r_{u}=1$ ) at 15 number of loading cycles [20] and the observed cyclic stress ratio value can be presented as cyclic strength of soil. In this regard the 


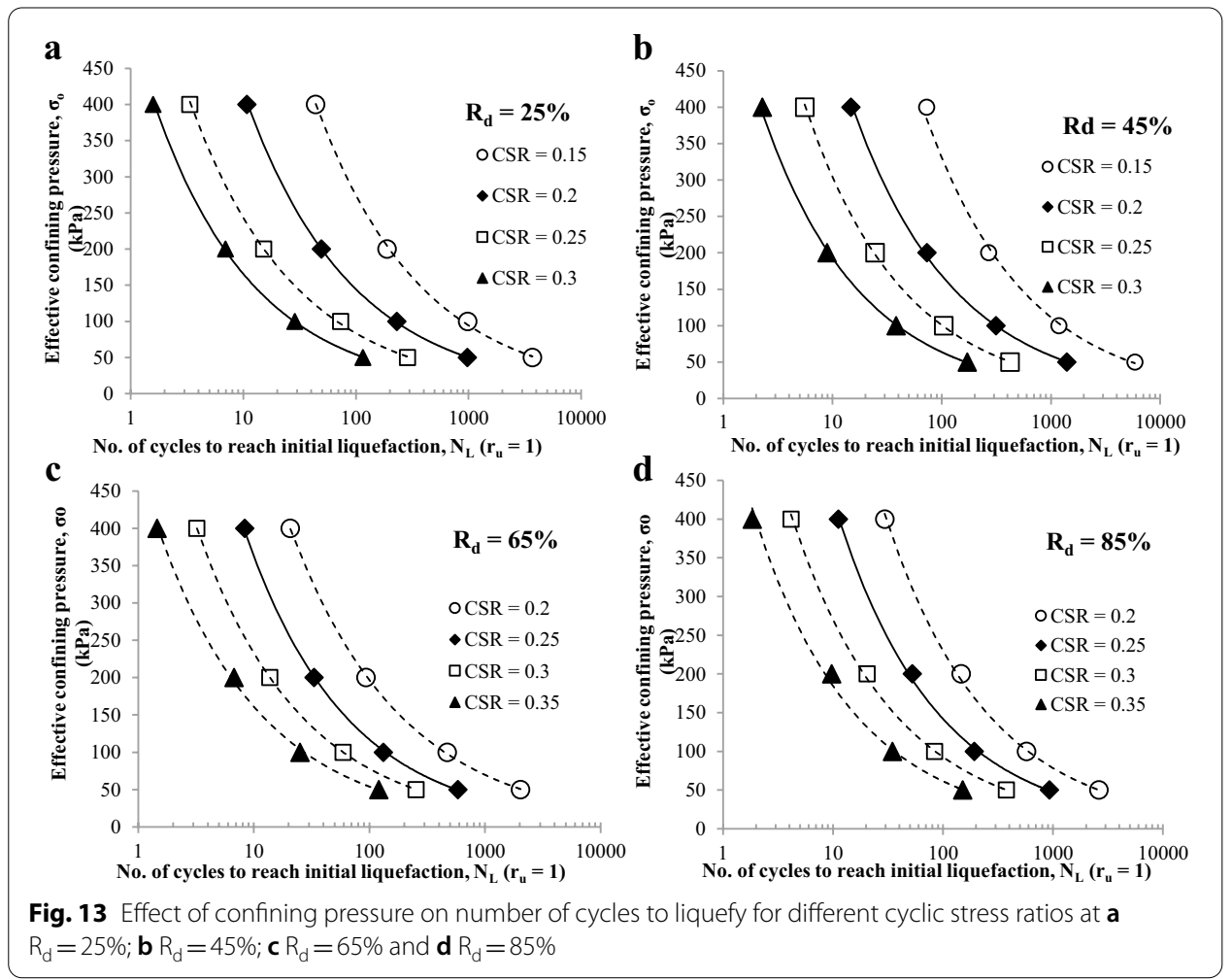

effect of density and effective confining pressure on cyclic strength of sand (represented in terms of CSR) has been illustrated in Fig. 15a (effect of effective confining pressure) and in Fig. 15b (effect of density) at $\mathrm{N}_{\mathrm{L}}=15$. It has been observed that the rate of change of cyclic stress ratio of sand (slope of the curve, i.e. rate of decrease in Fig. 15a) is quite higher for change of effective confining pressure rather than change of relative density (slope of the curve, i.e. rate of increase in Fig. 15b). This phenomenon signifies that liquefaction potential of sand influences greater by change of confining pressure rather than density. Again it has been re-established that increase in density increases cyclic strength of sand whereas increase in confining pressure diminishes cyclic strength of sand.

\section{Correlation between CSR with number of cycles for liquefaction, effective confining pressure and density of sand}

Test results obtained from 64 cyclic triaxial tests conducted at sinusoidal loading frequency of $1 \mathrm{~Hz}$. From the test data linear regression analysis has been done. The relative density of the soil has been introduced as void ratio function $\mathrm{f}(\mathrm{e})=1 /\left(0.3+0.7 \mathrm{e}^{2}\right)$, where $\mathrm{e}$ is the void ratio of soil. So a correlation has been obtained between cyclic strength of soil (CSR), number of cycles to liquefy $\left(\mathrm{N}_{\mathrm{L}}\right)$, effective confining pressure $\left(\sigma_{\mathrm{o}}\right)$ and relative density of soil (in terms of void ratio function, $\mathrm{f}(\mathrm{e})$ ). Previously, this type of correlation has been provided by [5, 32] in Eq. (1), where the cyclic strength of soil (CSR) is a function of $\mathrm{N}_{\mathrm{L}}$ and the multiplying constant, 'a' and power constant, 'b' depend on relative density of soil without considering the effect of effective confining pressure. A new 

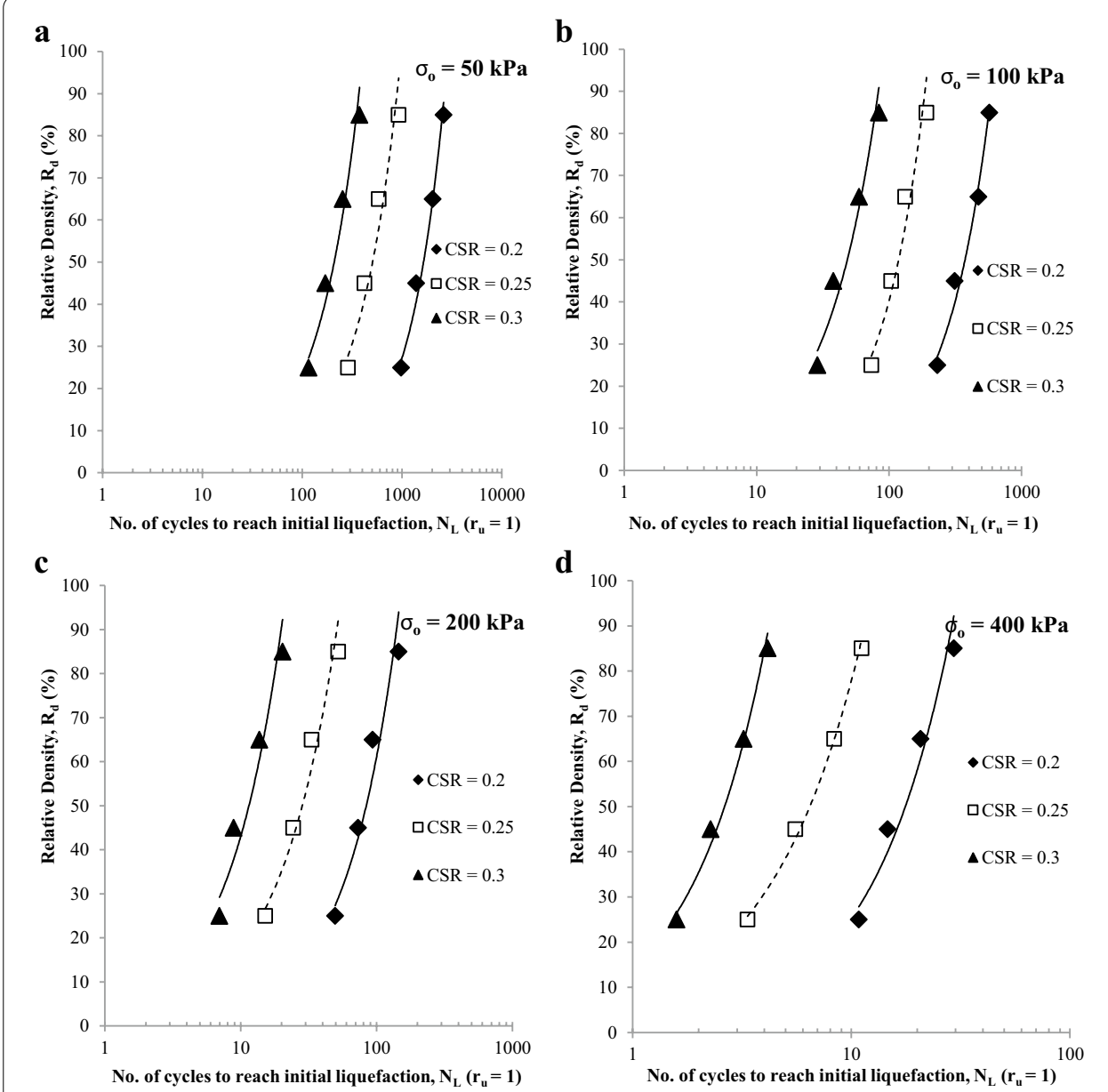

Fig. 14 Effect of relative density on number of cycles to liquefy for different cyclic stress ratios at a $\sigma_{0}=50 \mathrm{kPa} ; \mathbf{b} \sigma_{0}=100 \mathrm{kPa} ; \boldsymbol{c} \sigma_{0}=200 \mathrm{kPa}$ and $\mathbf{d} \sigma_{0}=400 \mathrm{kPa}$
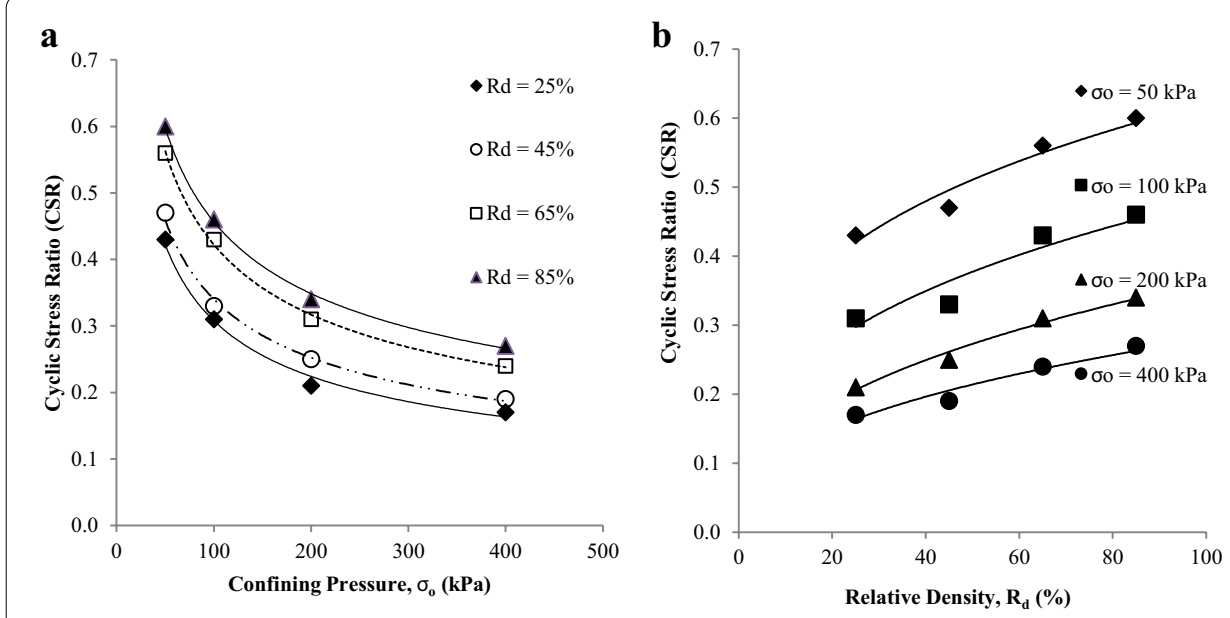

Fig. 15 Effect of $\mathbf{a}$ confining pressure and $\mathbf{b}$ relative density on the cyclic resistance (CSR) of sand for no. of cycles for initial liquefaction, $\mathrm{N}_{\mathrm{L}}=15$ 
correlation has been provided by linear regression by [34] in Eq. (3) by considering the effect of confining pressure in liquefaction potential of sand.

$$
C R R=0.6418 \times\left(\frac{R_{d}^{0.55}}{\sigma_{\mathrm{o}}}\right)^{0.287} .
$$

In this Eq. (3), the term CRR has been proposed by [34] is Cyclic Resistance Ratio of soil which can be defined as the cyclic stress ratio required to cause initial liquefaction of soil in 20 number of cyclic loading in stress controlled cyclic triaxial test. In this correlation it has been consider that the liquefaction will occur only at 20 numbers of loading cycles. But in all the cases of earthquake, liquefaction will not certainly happen at 20 numbers of cycles always. Liquefaction may occur at any number of loading cycles.

A new correlation of CSR of coastal Digha sand has been established by considering all the parameters i.e. number of loading cycles to cause liquefaction of soil $\left(\mathrm{N}_{\mathrm{L}}\right)$, effective confining pressure $\left(\sigma_{\mathrm{o}}\right)$, relative density (expressed in term of $\mathrm{f}(\mathrm{e})$ ) and it has been given in Eq. (4). The parameter, frequency has been excluded from this correlation, as it has been found frequency does not significantly affect cyclic strength of soil during liquefaction. So, the proposed equation is given by:

$$
C S R=\frac{0.52}{N_{L}^{0.2}} \times\left(\frac{\sigma_{\mathrm{o}}}{\mathrm{P}_{\mathrm{a}}}\right)^{-0.425} \times \frac{1}{\left(0.3+0.7 e^{2}\right)^{0.837}}
$$

It has been found the coefficient of determination $\left(R^{2}\right)$ is 0.96 . In Eq. (4) the term $P_{a}$ is the atmospheric pressure in $\mathrm{kPa}$ (same unit of effective confining pressure, $\sigma_{\mathrm{o}}$ ). This constant $\mathrm{P}_{\mathrm{a}}$ has been introduced to make the right hand side of the equation unit less. As the left hand side of this new correlation is cyclic stress ratio, a unit less quantity, so it is required to represent the right hand side in unit less also. As the terms number of loading cycles to cause liquefaction of soil $\mathrm{N}_{\mathrm{L}}$ and void ratio, e are both dimensionless parameters, it is required to represent $\sigma_{\mathrm{o}}$ in unit less term also. So the effective confining pressure has been divided by atmospheric pressure to make it a unit less quantity, provided that $\sigma_{o}$ and $P_{a}$ both is in same unit. So it can be stated that this equation as Eq. (4) is dimensionally correct, so it can be used in any unit system and can be used within the effective confining pressure range from $50 \mathrm{kPa}$ to $400 \mathrm{kPa}$. In this correlation the density of sand has been introduced as field void ratio or existing void ratio of the soil in the field. So using this correlation there is no need of performing relative density test of sand. By collecting the soil sample from the field and by calculating field void ratio test of sand, one can directly use the new proposed correlation to determine the cyclic strength of sand.

\section{Validation of the proposed correlation}

To assimilate the results obtained from cyclic triaxial tests and from correlation using Eq. (4), a comparative study has been done between predicted results using Eq. (4) and observed test results shown in Fig. 15a and b. Cyclic strength (CSR) required to cause failure of the Digha sand at 15 number of loading cycles at $R_{d}=25$ to $85 \%$ and at $\sigma_{o}=50$ to $400 \mathrm{kPa}$ has been taken in this study. So total 16 numbers of cyclic triaxial test results have been taken for validation and the observed value CSR from experiment and 


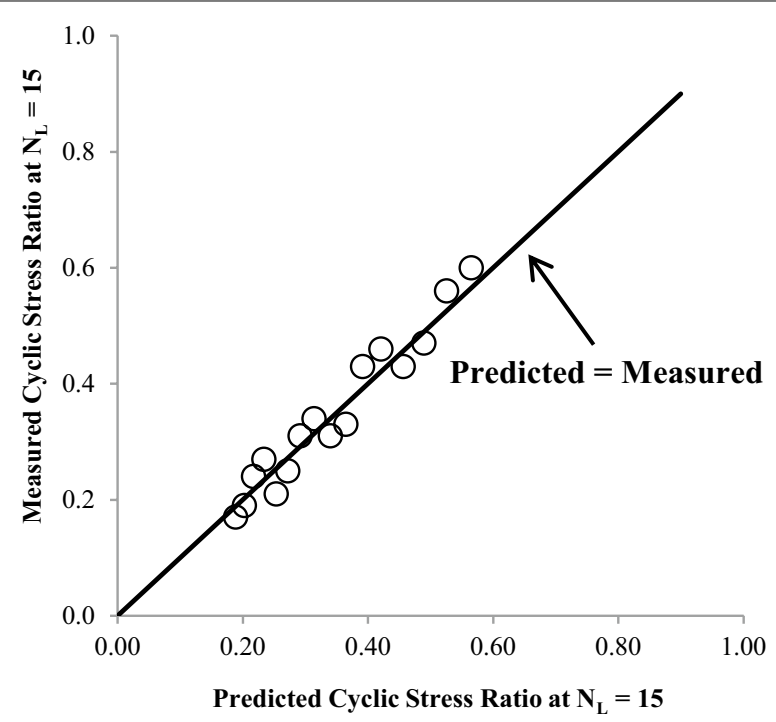

Fig. 16 Comparison of observed cyclic strength value form cyclic triaxial test with predicted cyclic strength value of Digha sand which induces liquefaction after 15 cycles

predicted value of CSR from Eq. (4) has been represented in Fig. 16. It has been found that the proposed correlationship approximate the observed CSR value very closely. So it can be stated that this proposed correlation can be used directly to estimate the cyclic strength of Digha sand.

\section{Limitation of the proposed correlation}

The new correlation proposed in this paper based on the experimental observations of stress controlled dynamic tests of coastal Digha sand. This newly proposed correlation has the following limitations:

i. As the sand skeleton structure, its grain size distribution, mineral constituents, size and shape of the sand particles can be found different at different locations, so it can be stated that this new correlation is valid quite well for those types of coastal sands which have the soil grain size distribution and skeleton structure similar to Digha sand.

ii. It has not been clearly understood that at very low effective confining pressure (less than $50 \mathrm{kPa}$ ) this correlation is valid or not.

\section{Conclusions}

A series of stress controlled cyclic triaxial tests have been carried out on coastal sand at Digha region located at eastern coast of India. All the tests have been performed on saturated sands by preparing the specimens by dry deposition methods by varying cyclic stress ratios, frequencies, soil density, effective confining pressures and number of loading cycles for initial liquefaction. From the experimental results the following conclusions have been drawn on coastal sand at Digha region:

(i) Frequency of loading cycles does not affect significantly the number of cycles for initial liquefaction of sand. But the cyclic strength of sand reduces as the number of 
cycles for initial liquefaction increases (for a particular density and a particular effective confining pressure).

(ii) For a particular cyclic stress ratio the liquefaction potential of sand increases with increase in relative density but the liquefaction potential reduces significantly with increase in effective confining pressure. This phenomenon explains that with increase in density of the soil shear strength of the sand increases which results higher liquefaction potential.

(iii) By selecting a particular number of loading cycles for initial liquefaction of sand (i.e. $\mathrm{N}_{\mathrm{L}}=15$ ) it has been observed that cyclic strength of sand (cyclic stress ratio) increases with increase in relative density but it reduces with increase in effective confining pressure. But the rate of change of cyclic stress ratio of sand (slope of the curve) is quite higher for change of effective confining pressure rather than change of relative density, which signifies that liquefaction potential of sand influences greater by change of effective confining pressure.

(iv) A new empirical correlation between cyclic stress ratio and change in effective confining pressure, sand density and number of loading cycles for initial liquefaction of coastal Digha sand has been developed by regression analysis. The tests results have been closely approximate the predicted results by using the new correlation and this correlation can be used at any system of units. This new correlation is valid quite well for those types of coastal sands which have the similar physical properties like Digha sand.

\section{Acknowledgements}

The authors are highly thankful to Civil Engineering Department of Jadavpur University for providing the opportunity to organize this research project along with arrangement of soil sample from Digha region and to provide permission to access the Soil Mechanics Laboratory of Civil Engineering Department of Jadavpur University to conduct several experimental works in the laboratory along with supporting manpower.

\section{Authors' contributions}

All authors contributed to the study conception and design. Material preparation, data collection and analysis were performed by PR and RBS. The first draft of the manuscript was written by PR and all authors commented on previous versions of the manuscript. Both authors read and approved the final manuscript.

\section{Funding}

Not applicable.

\section{Availability of data and materials}

Data transparency: the material has been collected by the corresponding author, Mr. Pinak Ray, from the site and all the relevant data regarding the material has been determined and generated by experimental works in the Soil Mechanics Laboratory of Department of Civil Engineering, Jadavpur University, Kolkata-700032, West Bengal, India

\section{Code availability}

Not applicable

\section{Competing interests}

On behalf of all authors, the corresponding author states that there is no conflict of interest.

Received: 11 June 2020 Accepted: 24 November 2020

Published online: 12 February 2021

\section{References}

1. ASTM D 2487 (2006) Standard practice for classification of soils for engineering purposes (unified soil classification system), ASTM International, West Conshohocken, p 2006

2. ASTM Standard D-5311-11 (2013) Standard test method for load controlled cyclic triaxial strength of soil. American Society of Testing and Materials, West Conshohocken

3. Biswas A, Das H (2014) "Characteristics of surface soil around Digha coastal region of West Bengal. J Hum Soc Sci 19(7):25-30

4. Castro G, Poulos J (1977) Factors affecting liquefaction and cyclic mobility. J Geotech Eng 103(6):501-516

5. Chattaraj R, Sengupta A (2016) Liquefaction potential and strain dependent dynamic properties of Kasai River sand. Soil Dyn Earthq Eng 90:467-475 
6. Dalal SS, Sahu RB (2011) Evaluation of Cpt Friction Ratio of some Soils of West Bengal. Indian Geotechnical Journal 41(4):206-214

7. Dasgupta S, Narula PL, Acharyya SK and Banerjee J (2000), Seismotectonic Atlas of India and its environs, Geological Society of India

8. De Alba P, Baldwin K, Janoo V, Roe G, Celikkol B (1984) Elastic-wave velocities and liquefaction potential. Geotech Test J 7(2):77-87

9. Hosri El, Biarez MS, Hicher PY (1984), Liquefaction characteristics of silty clay, Proc. 8th World Conf. Earthq. Eng., (3), San Francisco, CA; 277-284

10. Evans MD, Zhou S (1995) "Liquefaction of sand-gravel composites. J Geotech Eng 121(3):287-298

11. Finn WD, Pickering DJ, Bransby PL (1971) Sand liquefaction in triaxial and simple shear tests. J Geotech Eng 97(4):639-659

12. Hyodo M, Hyde AFL, Aramaki N (1998) Liquefaction of crushable soils. Geotechnique 48(4):527-543

13. Indian Meteorological Department - Earthquake Report, $28^{\text {th }}$ August, 2018 (www. imd.gov.in/pages/earthquake preilm.php)

14. IS: 1498 (1970) Classification and Identification of soils for general engineering purposes. Bureau of Indian Standards, New Delhi, p 1970

15. IS: 2720 (Part-3) (1981) Determination of specific gravity-fine, medium and coarse grained soils. Bureau of Indian Standards, New Delhi

16. IS: 2720 (Part-14) (1983) Determination of density index of cohesionless soils. Bureau of Indian Standards, New Delhi

17. Ishihara K, Kikuchi Y, Tsutsumi K (1983) Cyclic deformation behavior of sands under low confining pressure, In: Proceedings of the 18th Japanese National Soil Mechanics Research Meeting, JSSMFE

18. Jana A, Bhattacharya AK (2012) Assessment of coastal erosion vulnerability around Midnapur-Balasore coast, Eastern India using integrated remote sensing and GIS techniques.J Indian Soc Remote Sens. https://doi.org/10.1007/s1252 4-012-0251-2

19. Jana A, Biswas A, Maiti S, Bhattacharya AK (2013) Shoreline changes in response to sea level rise along Digha Coast, Eastern India: an analytical approach of remote sensing, GIS and statistical techniques. J Coast Conserv. https://doi. org/10.1007/s11852-013-0297-5

20. Krim A, Arab A, Bouferra R, Sadek M, Shahrour I (2016) Characteristics of cyclic shear behavior of sandy soils: a laboratory study. Arab J Sci Eng 41(10):3995-4005

21. Kumar SS, Krishna AM, Dey A (2017) Evaluation of dynamic properties of sandy soil at high cyclic strains. Soil Dyn Earthq Eng 99:157-167

22. Ladd RS (1978) Preparing test specimens using under compaction. Geotech Test J 1(1):16-23

23. Lee KL, Albaisa A (1974) Earthquake induced settlements in saturated sands. J Geotech Eng Div. 100(4):387-406

24. Lee, K.L. and Fitton, J.A. (1969), "Factors affecting the cyclic loading strength of soils", In: Vibration effect of earthquakes on soils and foundations, ASTM SPT 450, pp 71-95

25. Lee KL, Seed HB (1967) Cyclic stress conditions causing liquefaction of sand. J Soil Mech Found Div 93(SM1):47-70

26. Lin PS, Chang CW, Chang WJ (2004) Characterization of liquefaction resistance in gravelly soil: large hammer penetration test and shear wave velocity approach. Soil Dyn Earthq Eng 24:675-687

27. Maheshwari B, Kale S, Kaynia A (2012) Dynamic properties of Solani sand at large strains: a parametric study. Int J Geotech Eng 6(3):353-358

28. Mandal M, Dandapath PK, Bhushan S (2013) Digha Sankarpur Littoral Tract A Geographical Case Study. Int J Hum Soc Sci Invent 2(4):46-54

29. Morioka BT, Nicholson PG (2000), Evaluation of the liquefaction potential of calcareous sand, In: Proceedings of the International Offshore and Polar Engineering Conference, Seattle, WA, USA: 494-500

30. Peacock WH, Seed HB (1968) Sand liquefaction during cyclic loading simple shear conditions. J Geotech Eng 94(SM3):689-708

31. Pitchaikani JS, Kadharsha K, Mukherjee S (2016) Current status of seawater quality in Digha (India), northwestern coast of the Bay of Bengal. Environ Monit Assess. https://doi.org/10.1007/s10661-016-5383-3

32. Rad NS, Clough WG (1982) The influence of cementation on the static and dynamic behavior of sands Stanford. The John A. Blume Earthquake Engineering Center, Stanford Univ, Report No, California, p 59

33. Rao CH, Ramana GV (2010) Characterization of cyclic strength of Yamuna sand. Int J Earth Sci Eng 3(2):234-242

34. Salem M, Elmamlouk H, Agaiby S (2013) Static and cyclic behavior of North Coast calcareous sand in Egypt. Soil Dyn Earthq Eng. 55:83-91

35. Sandoval EA, Pando MA (2012) Experimental assessment of the liquefaction resistance of calcareous biogenous sands. Earth Sci Res J 16(1):55-63

36. Saxena SK, Reddy KR, Avramidis AS (1988) Liquefaction resistance of artificially cemented sand. J Geotech Engg 114(12):1395-1413

37. Seed HB, Lee KL (1966) Liquefaction of saturated sands during cyclic loading. J Soil Mech Found Div 92(SM6):105-134

38. Seed HB, Martin PP, Lysmer J (1976) Pore water pressure change during soil liquefaction. J Geotech Eng Div 102(4):323-346

39. Seed HB, Peacock WH (1971) Test procedures for measuring soil liquefaction characteristics. J Soil Mech Found Div. 97:1099-1119

40. Sharma SS, Ismail MA (2006) Monotonic and cyclic behaviour of two calcareous soils of different origins. J Geotech Geoenviron Eng 132(12):1581-1591

41. Silver L, Chan K, Ladd S, Lee L, Tiedemann A, Townsend C, Valera E, Wilson H (1976) Cyclic triaxial strength of standard test sand. J Geotech Eng 102:511-523

42. Sitharam TG, GovindaRaju L, Murthy BRS (2004) Evaluation of liquefaction potential and dynamic properties of silty sand using cyclic triaxial testing. Geotech Test J 27(5):423-429

43. Skempton AW (1954) The pore-pressure coefficients A and B. Geotechnique 4(4):143-147 
44. Stedman JD (1997), Effects of confining pressure and static shear on liquefaction resistance of Fraser River sand, B.A.Sc. thesis, The University of British Columbia, Canada

45. Tsuchida H (1970) Prediction and counter measure against the liquefaction in sand deposits. In: Abstract of the seminar in the Port and Harbor Research Institute, 3.1-3.33

46. Toki S, Tatsuoka F, Miura S, Yoshimi Y, Yasuda S, Makihara Y (1986) Cyclic undrained triaxial strength of sand by a cooperative test program. Soils Found 26(3):117-128

47. Townsend, F.C. (1977), "Review of factors affecting cyclic triaxial tests", Proc. Symp. Dynamic Geotech. Testing; ASTM $356-383$

48. Vucetic M, Dobry R (1988) Cyclic triaxial strain-controlled testing of liquefiable sands. In: Advanced Triaxial Testing of Soil and Rock, STP977: 475-485

49. Xenaki VC, Athanasopoulos GA (2003) Liquefaction resistance of sand-silt mixture: an experimental investigation of the effect of fines. Soil Dyn Earthq Eng 23:183-194

50. Yunoki Y, Ishihara K, Seki M, Yoneda Y (1982) The effect of the initial effective confining pressure on cyclic triaxial shear behavior of dense sand. In: Proceedings of the 17th Japanese National Soil Mechanics Research Meeting, JSSMFE: 1649-1652

\section{Publisher's Note}

Springer Nature remains neutral with regard to jurisdictional claims in published maps and institutional affiliations.

\section{Submit your manuscript to a SpringerOpen ${ }^{\circ}$ journal and benefit from:}

- Convenient online submission

- Rigorous peer review

- Open access: articles freely available online

- High visibility within the field

- Retaining the copyright to your article

Submit your next manuscript at $\mathbf{s p r i n g e r o p e n . c o m ~}$ 